\title{
Assessment of clinical and laboratory parameters that reflect inflammatory response and organ function in sepsis
}

\author{
Herdiman T Pohan
}

\begin{abstract}
Abstrak
Sepsis adalah kondisi klinis yang disebabkan oleh respon imun pejamu terhadap infeksi atau stimulus lain yang ditandai oleh inflamasi sistemik. Respon klinis pada sepsis dapat bervariasi tergantung dari tahap kompensasi atau dekompensasi, proses inflamasi dan kondisi pejamu. Tujuan penelitian ini adalah untuk menilai peran dari parameter (klinis, biokimia, hematologi, analisis gas darah dan koagulasi) dalam menunjang diagnosis sepsis. Dilakukan penelitian dengan disain potong lintang di unit rawat inap Rumah Sakit Umum Pusat Nasional Dr. Cipto Mangunkusumo, Jakarta, antara bulan Pebruari hingga Juli 2002. Empat puluh dua pasien memenuhi kriteria sepsis, sepsis berat dan renjatan septik. Dikumpulkan data klinis, sampel darah untuk pemeriksaan hematologi, biokimia, analisis gas darah dan koagulasi. Empat puluh dua subyek berpartisipasi dalam penelitian ini, dengan usia antara 19 hingga 78 tahun. Sebelas subyek memenuhi kriteria sepsis awal, 20 sepsis berat dan 11 renjatan septik. Pemeriksaan klinis menunjukkan Glasgow coma scale menurun secara bermakna pada sepsis berat dan renjatan septik. Denyut jantung, frekuensi nafas dan suhu tubuh meningkat pada semua kelompok. Pada sebagian besar subyek hemoglobin kurang dari 10 g/dl dan hematokrit kurang dari $30 \%$. Hitung lekosit meningkat pada lebih dari $80 \%$ subyek dengan jumlah lebih dari 15.000/mm ${ }^{3}$. Hitung trombosit menurun (kurang dari 50.000/ $\mathrm{mm}^{3}$ ) terutama pada renjatan septik. Kreatinin serum meningkat (> $2 \mathrm{mg} /$ dl) secara bermakna pada sepsis berat dan renjatan septik. Albumin menurun, $L D H$ dan prokalsitonin meningkat. Analisis gas darah menunjukkan: $\mathrm{pH}_{\text {dan }} \mathrm{HCO}_{3}$ menurun terutama pada renjatan septik; $\mathrm{PO}_{2}$ menurun pada sepsis berat dan renjatan septik; dan $\mathrm{PCO}_{2}$ kurang dari $32 \mathrm{mmHg}$ pada semua kelompok. Pemeriksaan koagulasi menunjukkan fibrinogen menurun secara bermakna pada renjatan septik, PT dan APTT memanjang pada sepsis berat dan renjatan septik lebih dari 18.8 dan 48 detik. D-dimer juga pada umumnya meningkat pada semua kelompok. Disimpulkan bahwa pemeriksaan klinis termasuk tingkat kesadaran, denyut jantung, tekanan arteri rata-rata, suhu dan frekuensi nafas, serta tambahan pemeriksaan laboratorium termasuk hematologi, biokimia, analisis gas darah dan koagulasi dapat digunakan sebagai parameter dalam mendiagnosis sepsis. Beberapa parameter yaitu tingkat kesadaran, kreatinin serum, hemoglobin, hitung trombosit dan fibrinogen dapat membedakan darajat sepsis. (Med J Indones 2005; 14: 26-32)
\end{abstract}

\begin{abstract}
Sepsis is a spectrum of clinical conditions caused by the host immune response to infection or other inflammatory stimuli characterized by systemic inflammation. Clinical response to sepsis could be varies according to compensate or decompensate state, inflammatory process and host condition. Aims of this study is to assess the role of some parameters (clinical and biochemical, hematology, arterial blood gas analysis and coagulation) in supporting the diagnosis of sepsis. A cross-sectional study was performed in the Internal Medicine Inpatient Unit of Dr. Cipto Mangunkusumo National General Hospital, Jakarta, from February to July 2002. Forty-two patients who fulfilled the criteria of sepsis, severe sepsis, and septic shock were enrolled in this study. Clinical details and blood specimens for hematological, biochemical, arterial blood gas analysis and coagulation were collected. There were 42 subjects who participated in the study, aged from 19 to 78 years old. Eleven subjects fulfilled the criteria for early sepsis, 20 severe sepsis and 11 septic shock. Clinical examination showed that the Glasgow coma scale (GCS) was significantly reduced in severe sepsis and septic shock. Heart rate, respiration rate and body temperature were increased in all groups. Hemoglobin levels mostly below $10 \mathrm{~g} / \mathrm{dl}$ and hematocrite levels below $30 \%$. The leucocyte counts were increased in more than $80 \%$, mostly above $15.000 / \mathrm{mm}^{3}$. The platelet count were low (below $50.000 / \mathrm{mm}^{3}$ ) especially in septic shock. The serum creatinine were significantly increased $(>2 \mathrm{mg} / \mathrm{dl})$ in severe sepsis and septic shock. Albumin was decreased, lactate dehydrogenase/LDH and procalcitonin were increased. The arterial blood gas analysis showed that: $\mathrm{pH}_{\text {and }} \mathrm{HCO}_{3}$ were decreased especially in septic shock; the $\mathrm{PO}_{2}$ was lower in severe sepsis and septic shock; and $\mathrm{PCO}_{2}$ was below $32 \mathrm{mmHg}$ in all groups. Coagulation examinations showed that fibrinogen was significantly decreased in septic shock; PT and APTT were prolong in severe sepsis and septic shock more than 18.8 and 48 seconds respectively. The d-dimer was also increased mostly in all groups. In conclusions that clinical examinations include level of consciousness, heart rate, mean arterial pressure, temperature and respiration rate and additional laboratory examinations include hamatological, biochemical, blood gas analysis and coagulation examinations can be used as parameters in diagnosis of sepsis. Some parameters include level of consciousness (Glasgow coma scale), serum creatinine, hemoglobin, platelet count and fibrinogen can differ sepsis according to severity. (Med J Indones 2005; 14: 26-32)
\end{abstract}

Keywords: Clinical response, SIRS, sepsis

Division of Tropical and Infectious Diseases, Department of Medicine, Faculty of Medicine University of Indonesia/ Dr. Cipto Mangunkusumo Hospital, Jakarta, Indonesia 
Sepsis is a spectrum of clinical conditions caused by the host immune response to infection or other inflammatory stimuli characterized by systemic inflammation. ${ }^{1}$ The clinical conditions of sepsis syndrome included : (1) clinical evidence of infection, (2) fever or hypothermia, (3) tachypnea, (4) tachycardia, and (5) impaired organ systems function or perfusion (such as altered mentation, hypoxemia, elevated plasma lactate level, or oliguria). ${ }^{2,3}$ In 1992 , the American College of Chest Physician and Society of Critical Care Medicine consensus established definitions for sepsis, systemic inflammatory response syndrome (SIRS), severe sepsis, septic shock and multiple organ dysfunction syndrome (MODS). These terms are still used in daily clinical practice up to now, considering the need for a practical guideline to recognize signs and symptoms of sepsis.

In the $31^{\text {st }}$ International Educational and Scientific Symposium of the Society of Critical Care Medicine in 2002, the term of acronym PIRO (P: predisposition, I: infection, R: response and $\mathrm{O}$ : organ failure) was also proposed aside of former terminology of sepsis. Several additional criteria beside SIRS were proposed, such as reduced consciousness, oliguria, skin manifestations, hypoglycemia, and thrombocytopenia. ${ }^{5}$ We had reported the risk factors, comorbidities, sites of infections, SIRS manifestation and organ failure of medical septic patients in our hospital. It seems that the PIRO criteria is relevant and support the accuracy in the diagnosis of sepsis. ${ }^{6}$

The host response in septic condition could be compensate in earlier stage or decompensate in later stage. In compensate stage the host response manifestation could be tachycardia, tachypnea, fever, leucocytosis, thrombocytosis, hyperglycemia and increased of acute phase reactants such as c-reactive protein (CRP), procalcitonin (PCT), LDH and albumin. In decompensate stage multiple organ dysfunction or failure could be manifest such as decreased of consciousness, hypothermia, hypotension, shock, decreased $\mathrm{PaO} 2$, increased serum creatinine, oliguria, anemia, leucopenia, thrombocytopenia and coagulopathy. In this study we will assess the role of these parameters in supporting the diagnosis of sepsis.

\section{METHODS}

The study was performed in the Internal Medicine Inpatient Unit of Dr. Cipto Mangunkusumo National
General Hospital, Jakarta, from February to July 2002 , along with the study on coagulation in sepsis. The study was designed to be cross-sectional. As many as 42 patients who fulfilled the criteria of sepsis, severe sepsis, and septic shock were willing to participate in the study (consent was obtained from the patient or closest relative). Patients with decompensate liver cirrhosis, nephrotic syndrome, blood malignancy, severe trauma, and pregnancy were not included in the study.

Clinical details and blood specimens for hematological, biochemical, blood gas analysis and coagulation; as well as microbiological culture were taken from the source of infection. The blood and other sample were taken for aerobe microbiological culture were performed under aseptic conditions using a sterile syringe. Serum samples taken for hematology (complete blood counts), biochemical examination (serum creatinine, albumin, lactate dehydorgenase/LDH, procalcitonin), arterial blood gas analysis ( $\mathrm{pH}, \mathrm{PCO}_{2}$, $\mathrm{PO}_{2}, \mathrm{HCO}_{3}$ ) and coagulation (prothrombin time/PT, activated partial thromboplastin time/aPTT, fibrinogen, d-dimer).

Study variables included level of consciousness, blood pressure, heart rate, respiration rate, temperature, hematocrite, leucocyte count, platelet count, PT, aPTT, fibrinogen, d-dimer, $\mathrm{pH}, \mathrm{PaO}_{2}$, $\mathrm{PaCO}_{2}, \quad \mathrm{HCO}_{3}$, serum creatinine, albumin, procalcitonin and $\mathrm{LDH}$ were evaluated. The criteria for sepsis used was based on the sepsis definition from American College of Chest Physician and Society of Critical Care Medicine, 1992. ${ }^{4}$ Data sorting and analysis was performed using a statistical computer program. Univariant analysis of categorical variable was portrayed in the form proportion and percentage. Correlations between variables were analyzed by Chi-square test. Confidence level $95 \%$ for all statistical test and a value of $p<0.05$ was considered statistically significant.

\section{RESULTS}

There were 42 subjects who participated in the study, aged from 19 to 78 years old, consisting of 22 females and 20 males. Eleven subjects fulfilled the criteria for sepsis $(26.2 \%), 20$ subjects for severe sepsis (47.6\%), and 11 subjects for septic shock $(26.2 \%)$. Chi-square analysis found a proportional distribution among these groups (Table 1). Chisquare test and Spearman correlation did not find a 
significant correlation between age and the degree of sepsis $(\mathrm{p}>0.05)$.

The most common sources of infection in this study were the lungs, skin and soft tissue, abdomen, and urinary tract. Lung infection comprised of pneumonia, skin and soft tissue infection erysipelas, gangrene and decubitus ulcer; intra-abdominal infection in the form of cholecystitis, cholangitis and peritonitis, urinary tract infection in the form of pyelonephritis. Comorbidities that present as risk and aggravating factors of sepsis were found among $88.1 \%$ of the subjects, comprising of diabetes mellitus, cardiovascular disease, cerebrovascular disease, chronic liver and renal disease, malignancy, or HIV infection. (Table 1)

Table 1. Subjects characteristics $(n=42)$

\begin{tabular}{|c|c|c|}
\hline & $\mathrm{n}$ & $\%$ \\
\hline \multicolumn{3}{|l|}{ Age $(\text { years })^{*}$} \\
\hline$\leq 40$ & 19 & 45.2 \\
\hline$\overline{41-59}$ & 11 & 28.6 \\
\hline$\geq 60$ & 11 & 28.6 \\
\hline \multicolumn{3}{|l|}{ Sex* } \\
\hline Male & 22 & 52.4 \\
\hline Female & 20 & 47.6 \\
\hline \multicolumn{3}{|l|}{ Sepsis severity* } \\
\hline Sepsis & 11 & 26.2 \\
\hline Severe sepsis & 20 & 47.6 \\
\hline Septic shock & 11 & 26.2 \\
\hline \multicolumn{3}{|l|}{ Comorbidities } \\
\hline Diabetes mellitus & 14 & 33.3 \\
\hline Cardiovascular diseases & 8 & 19 \\
\hline Cerebrovascular diseases & 5 & 11.9 \\
\hline Chronic kidney disease & 5 & 11.9 \\
\hline Chronic liver disease & 3 & 7.1 \\
\hline Malignancy & 1 & 2.3 \\
\hline HIV & 1 & 2.3 \\
\hline Absent & 5 & 11.9 \\
\hline \multicolumn{3}{|l|}{ Site of infection } \\
\hline Lung & 31 & 73.8 \\
\hline Skin and soft tissue & 10 & 23.8 \\
\hline Abdomen & 7 & 16.6 \\
\hline Urinary tract & 7 & 16.6 \\
\hline Heart & 3 & 7.2 \\
\hline Systemic & 2 & 4.7 \\
\hline Central venous catether & 1 & 2.4 \\
\hline ENT & 1 & 2.4 \\
\hline
\end{tabular}

* Chi-square test $\mathrm{p}>0.05$

\section{Clinical response in sepsis}

The clinical parameters of sepsis include: the levels of consciousness that represent function of central nervous system; heart rate and mean arterial pressure that represent function of cardiovascular system; respiration rate that represent function of respiratory system and body temperature that represent inflammatory process. The Glasgow coma scale (GCS) was significantly reduced in severe sepsis and septic shock. Heart rate, respiration rate and body temperature were increased mostly in all groups. Mean arterial pressure was decreased mainly in septic shock. (Table 2).

\section{Laboratory parameters in sepsis}

The laboratory parameters include the hematological examination (complete blood count), biochemical (serum creatinin, albumin, $\mathrm{LDH}$, procalcitonin), blood gas analysis and coagulation (PT, APTT, fibrinogen, d-dimer).

Complete blood count showed that hemoglobin levels mostly below $10 \mathrm{~g} / \mathrm{dl}$ and hematocrite below $30 \%$. In septic shock the hemoglobin and hematocrite were relatively higher due to probably leakage of the plasma. The leucocyte counts were increased in more than $80 \%$, mostly above $15.000 / \mathrm{mm}^{3}$. The platelet count were low (below $50.000 / \mathrm{mm}^{3}$ ) especially in septic shock. (Table 3).

The serum creatinine were significantly increased $(>2$ $\mathrm{mg} / \mathrm{dl}$ ) in severe sepsis and septic shock. Albumin was decreased (< $3 \mathrm{~g} / \mathrm{dl})$; LDH and procalcitonin were increased mostly in all groups (Table 4).

The arterial blood gas analysis showed that: $\mathrm{pH}$ and $\mathrm{HCO}_{3}$ were tent to decreased especially in septic shock; the $\mathrm{PO}_{2}$ was relatively lower in severe sepsis and septic shock; and $\mathrm{PCO}_{2}$ was mostly below 32 $\mathrm{mmHg}$ in all groups (Table 5).

Coagulation examinations showed that fibrinogen was significantly decreased in septic shock; in early and severe sepsis the fibrinogen was increased. The PT and APTT were prolonged mostly in all groups, but mainly in severe sepsis and septic shock more patients showed PT and APTT more than 18.8 and 48 seconds respectively. The d-dimer was also increased (> 375 $\mathrm{mg} / \mathrm{dl}$ ) mostly in all groups (Table 6). 
Table 2. Clinical response in Sepsis

\begin{tabular}{|c|c|c|c|c|}
\hline & $\begin{array}{c}\text { Early sepsis } \\
\text { n }(\%)\end{array}$ & $\begin{array}{c}\text { Severe sepsis } \\
\text { n }(\%)\end{array}$ & $\begin{array}{c}\text { Septic shock } \\
\text { n }(\%)\end{array}$ & $\begin{array}{l}\text { All } \\
\text { n }(\%)\end{array}$ \\
\hline \multicolumn{5}{|l|}{ Conciousness (GCS)* } \\
\hline 15 & $9(81.8)$ & $2(10.0)$ & $1(9.1)$ & $12(28.5)$ \\
\hline $10-14$ & $2(18.2)$ & $13(65.0)$ & $8(72.7)$ & $23(54.8)$ \\
\hline$<10$ & 0 & $5(25.0)$ & $2(18.2)$ & $7(16.7)$ \\
\hline \multicolumn{5}{|l|}{ Heart rate } \\
\hline$>120$ & 0 & $1(5.0)$ & $1(9.1)$ & $2(4.8)$ \\
\hline $100-120$ & $10(90.9)$ & $15(75.0)$ & $6(54.5)$ & $31(73.8)$ \\
\hline$<100$ & $1(9.1)$ & $4(20.0)$ & $4(36.4)$ & $9(21.4)$ \\
\hline \multicolumn{5}{|c|}{ Mean arterial pressure $(\mathrm{mmHg})$} \\
\hline$>90$ & $2(18.2)$ & $6(30.0)$ & $1(9.1)$ & $9(21.4)$ \\
\hline $70-90$ & $8(72.7)$ & $11(55.0)$ & $4(36.4)$ & $23(54.8)$ \\
\hline$<70^{\xi}$ & $1(9.1)$ & $3(15.0)$ & $6(54.5)$ & $10(23.8)$ \\
\hline \multicolumn{5}{|l|}{ Temperature $\left({ }^{\circ} \mathrm{C}\right)$} \\
\hline$>39$ & $3(27.3)$ & $5(25.0)$ & $4(36.4)$ & $12(28.5)$ \\
\hline $37-39$ & $8(72.7)$ & $13(65.0)$ & $6(54.5)$ & $27(64.3)$ \\
\hline$<37$ & 0 & $2(10.0)$ & $1(9.1)$ & $3(7.2)$ \\
\hline \multicolumn{5}{|l|}{ Respiration rate } \\
\hline$>28$ & $8(72.7)$ & $12(60.0)$ & 7 (63.6) & $27(64.2)$ \\
\hline $24-28$ & $3(27.3)$ & $8(40.0)$ & $2(18.2)$ & $13(31)$ \\
\hline$<24$ & 0 & 0 & $2(18.2)$ & $2(4.8)$ \\
\hline
\end{tabular}

Table 3. Hematological examination in sepsis

\begin{tabular}{|c|c|c|c|c|}
\hline & $\begin{array}{c}\text { Early sepsis } \\
\text { n }(\%)\end{array}$ & $\begin{array}{c}\text { Severe sepsis } \\
\text { n }(\%)\end{array}$ & $\begin{array}{c}\text { Septic shock } \\
\text { n }(\%)\end{array}$ & $\begin{array}{c}\text { All } \\
\text { n }(\%)\end{array}$ \\
\hline \multicolumn{5}{|l|}{ Hemoglobin* (g/dl) } \\
\hline$>10$ & $4(36.4)$ & $2(10.0)$ & $6(54.5)$ & $12(28.5)$ \\
\hline $8-10$ & $3(27.3)$ & $13(65.0)$ & $2(18.2)$ & $18(43)$ \\
\hline$<8$ & $4(36.4)$ & $5(25.0)$ & $3(27.3)$ & $12(28.5)$ \\
\hline \multicolumn{5}{|l|}{ Hematocrite (\%) } \\
\hline$>40$ & 0 & 0 & $1(9.1)$ & $1(2.4)$ \\
\hline $30-40$ & $5(45.5)$ & $4(20.0)$ & $5(45.5)$ & $14(33.4)$ \\
\hline $24-29$ & $1(9.1)$ & $9(45.0)$ & $2(18.2)$ & $12(28.5)$ \\
\hline$<24$ & $5(45.5)$ & $7(35.0)$ & $3(27.3)$ & $15(35.7)$ \\
\hline \multicolumn{5}{|c|}{ Leucocyte counts $\left(10^{3} / \mathrm{mm}^{3}\right)$} \\
\hline$>15$ & $7(63.6)$ & $14(70.0)$ & $6(54.5)$ & $27(64.2)$ \\
\hline $10-15$ & $3(27.3)$ & $3(15.0)$ & $2(18.2)$ & $8(19.2)$ \\
\hline $5-10$ & $1(9.1)$ & $3(15.0)$ & $2(18.2)$ & $6(14.2)$ \\
\hline$<5$ & 0 & 0 & $1(9.1)$ & $1(2.4)$ \\
\hline \multicolumn{5}{|c|}{ Platelet counts* $\left(10^{3} / \mathrm{mm}^{3}\right)$} \\
\hline$>150$ & $7(63.3)$ & $13(65.0)$ & $3(27.3)$ & $23(54.7)$ \\
\hline $100-149$ & $2(18.2)$ & $2(10.0)$ & 0 & $4(9.5)$ \\
\hline$<100$ & $2(18.2)$ & $5(20.0)$ & $8(72.7)$ & $15(35.8)$ \\
\hline
\end{tabular}

* Chi square test $\mathrm{p}<0.05$ 
Table 4. Biochemical parameters in sepsis

\begin{tabular}{|c|c|c|c|c|}
\hline & $\begin{array}{c}\text { Early sepsis } \\
\text { n }(\%)\end{array}$ & $\begin{array}{c}\text { Severe sepsis } \\
\text { n }(\%)\end{array}$ & $\begin{array}{c}\text { Septic shock } \\
\text { n }(\%)\end{array}$ & $\begin{array}{l}\text { All } \\
\text { n }(\%)\end{array}$ \\
\hline \multicolumn{5}{|c|}{ Serum creatinine* (mg/dl) } \\
\hline$<1.0$ & $5(45.5)$ & $2(10.0)$ & 0 & $7(16.7)$ \\
\hline $1.0-2.0$ & $5(45.5)$ & $10(50.0)$ & $3(27.3)$ & $18(42.8)$ \\
\hline$>2.0$ & $1(8.1)$ & $8(40.0)$ & $8(72.7)$ & $17(40.4)$ \\
\hline \multicolumn{5}{|l|}{ Serum albumin (g/dl) } \\
\hline$<2.0$ & $1(9.1)$ & $1(5.6)$ & 0 & $2(5.4)$ \\
\hline $2.0-3.0$ & $5(45.5)$ & $11(61.1)$ & $5(55.5)$ & $21(56.7)$ \\
\hline$>3.0$ & $4(36.4)$ & $6(33.3)$ & $4(44.4)$ & $8(37.9)$ \\
\hline \multicolumn{5}{|c|}{ Lactate dehydrogenase/LDH (U/L) } \\
\hline$<193$ & $3(30.0)$ & $1(5.9)$ & $2(22.2)$ & $6(16.7)$ \\
\hline $194-275$ & 0 & $4(23.5)$ & $1(11.1)$ & $5(13.9)$ \\
\hline$>275$ & $7(70.0)$ & $12(70.6)$ & $6(66.7)$ & $25(69.4)$ \\
\hline \multicolumn{5}{|l|}{ Procalcitonin (ng/ml) } \\
\hline$<2$ & $2(40.0)$ & $3(33.3)$ & $2(25.0)$ & $7(31.5)$ \\
\hline $2-10$ & $3(60.0)$ & $1(11.1)$ & $1(12.5)$ & $5(22.5)$ \\
\hline$>10$ & 0 & $5(55.5)$ & $5(62.5)$ & $10(45)$ \\
\hline
\end{tabular}

* Chi square test $\mathrm{p}<0.05$

Table 5. Arterial blood gases analysis in sepsis

\begin{tabular}{|c|c|c|c|c|}
\hline & $\begin{array}{c}\text { Early sepsis } \\
\text { n }(\%)\end{array}$ & $\begin{array}{c}\text { Severe sepsis } \\
\text { n }(\%)\end{array}$ & $\begin{array}{c}\text { Septic shock } \\
\text { n }(\%)\end{array}$ & $\begin{array}{l}\text { All } \\
\text { n }(\%)\end{array}$ \\
\hline \multicolumn{5}{|l|}{ pH } \\
\hline$<7.35$ & $2(18.2)$ & $5(25.0)$ & $5(45.5)$ & $12(28.7)$ \\
\hline $7.35-7.45$ & $7(63.6)$ & $10(50.0)$ & $3(27.3)$ & $20(47.6)$ \\
\hline$>7.45$ & $2(18.2)$ & $5(25.0)$ & $3(27.3)$ & $10(23.7)$ \\
\hline \multicolumn{5}{|l|}{$\mathrm{PCO}_{2}(\mathrm{mmHg})$} \\
\hline$<32$ & $9(81.8)$ & $11(55.0)$ & $9(81.8)$ & $29(69)$ \\
\hline $32-35$ & 0 & $5(25.0)$ & 0 & $5(11.9)$ \\
\hline $35-45$ & $2(18.2)$ & $4(20.0)$ & $1(9.1)$ & $7(16.7)$ \\
\hline$>45$ & 0 & 0 & $1(9.1)$ & $1(2.4)$ \\
\hline \multicolumn{5}{|l|}{$\mathrm{PO}_{2}(\mathrm{mmHg})$} \\
\hline$<60$ & $2(18.2)$ & $2(10.0)$ & $1(9.1)$ & $5(12)$ \\
\hline $60-80$ & $2(18.2)$ & $9(45.0)$ & $5(45.5)$ & $16(38)$ \\
\hline$>80$ & $7(63.6)$ & $9(45.0)$ & $5(45.5)$ & $21(50)$ \\
\hline \multicolumn{5}{|l|}{$\mathrm{HCO}_{3}(\mathrm{meq} / \mathrm{L})$} \\
\hline$<15$ & $3(30.0)$ & $7(35.0)$ & $8(72.7)$ & $18(43.9)$ \\
\hline $16-22$ & $4(40.0)$ & $6(30.0)$ & $2(18.2)$ & $12(29.3)$ \\
\hline$>22$ & $3(30.0)$ & $7(35.0)$ & $1(9.1)$ & $11(26.8)$ \\
\hline
\end{tabular}

* Chi square test $\mathrm{p}<0.05$ 
Table 6. Coagulation parameters in sepsis

\begin{tabular}{|c|c|c|c|c|}
\hline & $\begin{array}{c}\text { Early sepsis } \\
\text { n }(\%)\end{array}$ & $\begin{array}{c}\text { Severe sepsis } \\
\text { n }(\%)\end{array}$ & $\begin{array}{c}\text { Septic shock } \\
\text { n }(\%)\end{array}$ & $\begin{array}{l}\text { All } \\
\text { n }(\%)\end{array}$ \\
\hline \multicolumn{5}{|c|}{ Prothrombin time (seconds) } \\
\hline$<9.7$ & 0 & 0 & $1(10.0)$ & $1(2.6)$ \\
\hline $9.7-12.7$ & $1(9.1)$ & $3(15.0)$ & $1(10.0)$ & $5(12.1)$ \\
\hline $12.8-18.7$ & $10(90.9)$ & $12(60.0)$ & $4(40.0)$ & $26(63.4)$ \\
\hline$>18.8$ & 0 & $5(25.0)$ & $4(40.0)$ & $9(21.9)$ \\
\hline \multicolumn{5}{|l|}{ aPTT (seconds) } \\
\hline$<26$ & 0 & 0 & $1(10.0)$ & $1(2.6)$ \\
\hline $26-36$ & $2(18.2)$ & $2(10.0)$ & $1(10.0)$ & $5(12)$ \\
\hline $37-48$ & $5(45.5)$ & $7(35.0)$ & $1(10.0)$ & $13(31.7)$ \\
\hline$>48$ & $4(36.4)$ & $11(55.0)$ & $7(35.0)$ & $22(53.6)$ \\
\hline \multicolumn{5}{|l|}{ Fibrinogen* (mg/dl) } \\
\hline$>350$ & $10(90.9)$ & $18(94.7)$ & $6(54.5)$ & $34(82.9$ \\
\hline $100-350$ & $1(9.1)$ & $1(5.3)$ & $3(27.3)$ & $5(11.9)$ \\
\hline$<100$ & 0 & 0 & $2(18.2)$ & $2(5.2)$ \\
\hline \multicolumn{5}{|l|}{ D-dimer (mg/dl) } \\
\hline$<375$ & $3(30.0)$ & $5(25.0)$ & $4(40.0)$ & $12(30)$ \\
\hline $375-1000$ & $5(50.0)$ & $8(40.0)$ & $2(20.0)$ & $15(37.5)$ \\
\hline$>1000$ & $2(20.0)$ & $7(35.0)$ & $4(40.0)$ & $13(32.5)$ \\
\hline
\end{tabular}

- Chi square test $\mathrm{p}<0.05$

\section{DISCUSSION}

Clinical manifestations of sepsis could be varies depends on the inflammatory process, severity of infection and organ systems involved. The response of organ systems in sepsis could be compensate in early stage, and will be exhausted or failure in later stage. The ability of organs to response and compensate were differ according to preexist condition such as age, underlying diseases and comorbidities. ${ }^{2,7}$

In this study we assessed the clinical and laboratory parameters that represent the organ function and inflammatory process. GCS that represent the level of consciousness can be used as clinical parameter for sepsis severity. Level of consciousness could be affected in sepsis because the inflammatory process and disturbance of cerebral perfusion and oxygenization. Mean arterial pressure and heart rate that represent the cardiovascular system will compensate in early sepsis because of increasing of oxygen demand. The respiration rate, $\mathrm{pH}, \mathrm{PCO}_{2}$ and $\mathrm{PO}_{2}$ that represent the respiratory system will also compensate and balance the acid-base status. Serum creatinine that represent the kidney function were significantly increased in severe sepsis and septic shock.
Other parameters that represent inflammatory process such as body temperature, leucocyte count, LDH and procalcitonin will increased in early stage, but in decompensate stage hypothermia and leucopenia could be occurred, due to decreasing of inflammatory reaction. Other organs will also affected by inflammatory process such as liver (decreased of serum albumin), hematological (anemia, thrombocytopenia) and coagulation (prolong PT and APTT, low fibrinogen, increased of d-dimer). In early stage the PT and APTT were relatively shortened, fibrinogen increased due to compensation; but in decompensate condition the PT and APTT prolonged and the fibrinogen levels decreased. Some other parameters, which also potentially used as clinical parameters in sepsis, such as c-reactive protein, plasma cytokine levels and plasma lactate were not evaluated in this study.

Procalcitonin is polypeptide from calcitonin which is produced by thyroid C-cell. Endotoxin will stimulate its production and the levels will increase in bacterial infection and sepsis. ${ }^{8}$ Thrombocytopenia and coagulopathy occur, as consequence of inflammatory mediators which caused endothelial dysfunction and increase the tissue factor expression. The consumptive coagulopathy (prolong PT, APTT, low fibrinogen and increase d-dimer), low natural anticoagulant (protein C, 
protein $\mathrm{S}$ and antithrombin), thrombocytopenia and organ failure will occur in decompensate condition (disseminated intravascular coagulation). ${ }^{9}$

Balk, et al had evaluated the clinical manifestation in sepsis. They proposed the sepsis syndrome that include alteration of body temperature, tachipnea or hyperventilation, tachicardia, leucocytosis or leucopenia, alter blood pressure, thrombocytopenia, coagulopathy and alter mental status. The clinical syndrome of sepsis is caused by circulating inflammatory mediators. Fever is the sign of inflammation and infection, tachipnea is the sign of widening alveolar arterial gradient, tachipnea is the sign of hyperdynamic of cardiovascular system. Some of this symptoms are related to increasing of mortality rate include hypothermia, reduce of consciousness, hypotension and shock. ${ }^{2,3,10,11,12}$

It is important in diagnosis and treatment of sepsis, to pay attention and monitoring the response of organ systems that affected. The clinical parameter that usually performed as clinical diagnosis had been used in SIRS criteria; other parameters that reflected physiological of organ function potentially used beside of this criteria.

\section{CONCLUSION}

Clinical examinations include level of consciousness, heart rate, mean arterial pressure, temperature and respiration rate and additional laboratory examinations include hamatological, biochemical, blood gas analysis and coagulation examinations can be used as parameters in diagnosis of sepsis. Some parameters such as level of consciousness (Glasgow coma scale), serum creatinine, hemoglobin, platelet count and fibrinogen can differ sepsis according to severity.

\section{Acknowledgement}

We thank Dr. Lugiyanti Sukrisman for her support in this study.

\section{REFERENCES}

1. Martin GS. The complex role of coagulation in the patophysiology of sepsis. [cited 2001 February]. Available from: http://www.medscape.com/medscape/cno/2001/SCCM/St ory. cfm? story id $=2081$.

2. Balk RA. Severe sepsis and septic shock: definitions, epidemiology and clinical manifestation. Crit Care Clin. 2000; 16(2):179-92.

3. Bone RC, Fisher CJ, Clemmer TP, Slotman GJ, Metz CA, Balk RA, et al. Sepsis syndrome: a valid clinical entity. Crit Care Med 1989; 17(5): 389-93.

4. Members of the American College of Chest Physician/Society of Critical Care Medicine Consensus Conference Committee. American College of Chest Physician/Society of Critical Care Medicine Consensus Conference: Definition for sepsis and organ failure and guidelines for the use of innovative therapies in sepsis. Crit Care Med 1992;20:864-74.

5. Martin GS. Sepsis: an evolution of concept and definition. [cited 2002 April 11]. Available from: http://www.medscape.com/viewarticle/427188.

6. Widodo D. The clinical, laboratory, and microbiological profile of patients with sepsis at the Internal Medicine inpatient unit of Dr. Cipto Mangunkusumo National General Hospital, Jakarta.. Med J Indones 2004; 13 (2): 90-5.

7. Rodrigues JC, Fein AM. Diagnostic approach and clinical manifestation of severe sepsis. In: Fein AM, Abraham EM, Balk RA, et al (eds). Sepsis and multiple organ failure. Baltimore: Williams aned Wilkins. 1997. pp 269-76.

8. Brunkhorst FM, Wegscheider K, Foryeki ZF, Brunkhorst R. Procalcitonin for early diagnosis and differentiation of SIRS, sepsis, severe sepsis and septic shock. Intensive Care Med 2000; 26: S148-52

9. Thijs LG. Patophysiology of coagulation and fibrinolysis in sepsis. Crit Care and Shock. 1998;1:15-25.

10. Bone RC. Let's agree on terminology: definition of sepsis. Crit Care Med 1991; 19(7): 973-76.

11. Casey LC. Immunologic response to infection and its role in septic shock. Crit Care Clin 2000; 16 (2): 193-213

12. Dhainaut JF, Marin N. Sepsis induce multiple organ dysfunction syndrome. In: Dhainaut JF, Thijs L, Park G (eds). Septic shock. London. WB Saunders Co. 2000. p.321-26. 